\title{
Studi Komparatif Dan Kontrastif Nilai-Nilai Fonologi Antara Bahasa Indonesia Dan Bahasa Arab Bagi Mahasiswa Program Studi Pendidikan Bahasa Arab UIN Sunan Ampel Surabaya
}

\author{
Muflihah \\ Universitas Sunan Ampel Surabaya \\ muflihah@uinsby.ac.id
}

\begin{abstract}
Abstrack: Phonology ('Ilmu Așwat) is a branch of linguistics that talks about the sound of language that is able to distinguish the meaning of a word or a science that studies the sounds of particular language according to its function to distinguish lexical meaning. The first problem in learing oral language is the problem of his speech. Before someone learns the meaning of various words and grammar, he must recognize the sounds used in that language. Therefore, the researcher proposes the title to find out some of the problems examined in this study: how to compare the phonological values between Arabic and Indonesian language in order to develop teaching materials for așwat sciense materials to identify these problems in depth and comprehensively. This research uses qualitaive-descriptive. The results of this study are a comparative study of phonological values between Arabic and Indonesian is the possibility of identical characteristics between both of them in term of places of articulation and the sound charasteristics.
\end{abstract}

Key word: Comparative and Constrastive, Phonology, Arabic, Indonesian

\begin{abstract}
Abstrak: Fonologi (Ilmu Aswat) adalah cabang ilmu bahasa yang membicarakan bunyi bahasa yang mampu membedakan makna suatu kata atau ilmu yang mempelajari bunyi-bunyi bahasa tertentu menurut fungsinya, untuk membedakan makna leksikal. Masalah yang pertama dalam mempelajari bahasa lisan, terutama bahasa asing dan bahasa daerah, ialah masalah ucapannya. Sebelum seseorang mempelajari makna berbagai kata dan tata bahasa, ia harus mengenali bunyi-bunyi yang digunakan dalam bahasa tersebut. Oleh karena itu, peneliti mengajukan judul tersebut untuk mengetahui beberapa persoalan yang dikaji dalam penelitian ini, yaitu tentang :Bagaimana komparatif nilai-nilai fonologi antara Bahasa Bahasa Arab dan Bahasa Indonesia guna mengembangkan bahan ajar materi ilmu Aswat Untuk mengidentifikasi permasalahan tersebut secara mendalam dan menyeluruh, penelitian ini menggunakan Penelitian ini menggunakan metode deskriptifkualitatif. Hasil penelitian ini adalah: Studi komparatif nilai-nilai fonologi antara Bahasa Bahasa Arab dan Bahasa Indonesia adalah dimungkinkan adanya sifat identik antara bahasa Arab dan bahasa Inggris dari segi tempat keluarnya suara dan sifat suara.
\end{abstract}

Kata kunci : Komparatif Dan Kontrastif, Fonologi, Bahasa Arab, Bahasa Indonesia. 


\section{PENDAHULUAN}

Bahasa adalah suatu sistem lambang bunyi yang dipakai manusia untuk tujuan komunikasi. Bahasa pada hakikatnya adalah bunyi. Dalam menggunakan bahasa, bunyi yang diucapkan berhubungan dengan arti tertentu.Seseorang yang menguasai bahasa tertentu dapat mengenal bunyi-bunyi itu dirangkaikan, sehingga merupakan ujaran yang bermakna dan perkembangan bahasa-bahasa dilihat dari aspek bunyi mengalami perkembangan yang sangat cepat. Kebanyakan perkembangan tersebut terbagi berdasarkan siḡah (sorf), nahwu, mufradat, dan uslub. Oleh karena itu, sudah jelas bahwa aspek yang diucapkan dalam bahasa itu harus lebih banyak dikaji daripada aspek yang ditulis. Alasannya ialah bahwa bahasa itu berkumpul dalam susunan dan kelompok bunyi yang diperindah oleh makna yang tidak dijelaskan dalam perkataan yang tertulis.

Oleh karena itu pengajaran Bahasa Arab dan Bahasa Indonesia hendaknya mempunyai ruang lingkup dan tujuan yang menumbuhkan kemampuan mengungkapkan pikiran dan perasaan dengan menggunakan bahasa yang baik dan benar agar seseorang dapat berkomunikasi dengan baik dan benar.

Dalam hal ini, fonologi (Ilmu Aswat) adalah cabang ilmu bahasa yang membicarakan bunyi bahasa yang mampu membedakan makna suatu kata atau ilmu yang mempelajari bunyi-bunyi bahasa tertentu menurut fungsinya, untuk membedakan makna leksikal . Masalah yang pertama kali dihadapi oleh sesorang dalam mempelajari bahasa lisan, terutama bahasa asing dan bahasa daerah, ialah masalah ucapannya. Sebelum mempelajari makna berbagai kata dan tata bahasa yang akan dihadapinya, terlebih dahulu ia harus mengenali bunyi-bunyi yang digunakan di dalamnya. 
Banyak kajian teori mengenai bahasa ini, salah satunya kajian tentang fonologi, dan kajian fonologi adalah bunyi-bunyi bahasa sebagai satuan terkecil dari ujaran beserta dengan "gabungan" antar bunyi yang membentuk silabel atau suku kata. Serta juga dengan unsur-unsur suprasegmentalnya, seperti tekanan, nada, hentian dan durasi ${ }^{1}$.

Bunyi-bunyi bahasa ketika diucapkan ada yang bisa disegmen-segmenkan, diruas-ruaskan, dan dipisah-pisahkan. Bunyi-bunyi yang bisa disegmentasikan ini disebut bunyi segmental. Tetapi ada juga yang tidak bisa disegmentasikan karena kehadiran bunyi ini selalu mengiringi, menindih, atau menemani bunyi segmental. Bunyi ini disebut bunyi suprasegmental2.

Selain kajian diatas fonologi juga mengkaji tentang mekanisme artikulasi atau alat ucap yang bekerja atau bergerak ketika menghasilkan bunyi bahasa. Dan mekanisme artikulasi Bahasa Indonesia dan Bahasa Arab tentunya terdapat persamaan dan perbedaan.

Dengan demikian peneliti ingin mengadakan penelitian tentang studi komparatif dan kontrastif nilai-nilai fonologi antara Bahasa Indonesia dan Bahasa Arab Bagi Mahasiswa Program Studi Pendidikan Bahasa Arab UIN Sunan Ampel Surabaya.

\section{METODOLOGI PENELITIAN}

\section{Jenis Penelitian}

\footnotetext{
1 Masnur Muslich, 2008, Fonologi bahasa indonesia tinjauan deskriptif sistem bunyi bahasa Indonesia, jakarta; hal 01-02.

2 Ibid Masnur Muslich, 2008, Fonologi bahasa indonesia tinjauan deskriptif sistem bunyi bahasa Indonesia, jakarta; hal 05.
} 
Jenis penelitian yang digunakan dalam penelitian ini adalah jenis penelitian deskriptif kuantitatif. Jenis survei deskriptif digunakan untuk menggambarkan populasi yang sedang diteliti. Fokus riset ini adalah perilaku yang sedang terjadi dan terdiri dari data variabel. Dengan metode ini peneliti dapat mengumpulkan data - data yang diperlukan. Penyebaran ini akan dilakukan pada mahasiswa Fakultas Tarbiyah yang sedang mengikuti Pembelajaran ilmu aswat.

\section{Teknik Pengumpulan Data}

Ada beberapa teknik pengumpulan data yang digunakan oleh peneliti dalam penelitian kali ini. Beberapa teknik itu antara lain:

\section{Observasi (Pengamatan)}

Observasi adalah cara pengumpulan data dengan cara melakukan pencatatan secara cermat dan sistematis fenomena-fenomena yang diselidiki. ${ }^{3}$ Tujuan dari observasi ini adalah untuk memperoleh informasi yang lengkap terkait pembelajaran materi ilmu Aswat bagi mahasiswa PBA. Interview.

Teknik pengumpulan data yang digunakan peneliti untuk mendapatkan keterangan-keterangan lisan melalui bercakap-cakap dan berhadapan muka dengan orang yang dapat memberikan keterangan kepada si peneliti.Dalam hal ini peneliti tidak hanya mengamati dari luarnya saja, akan tetapi juga menanyakan secara langsung kepada beberapa mahasiswa mengenai penerapan materi ilmu Aswat.

\section{Dokumentasi}

Dokumentasi yaitu mencari data mengenai hal-hal atau variable yang berupa catatan ,transkrip, buku, surat kabar, majalah, agenda dan sebagainya. Teknik dokumenter merupakan Teknik yang tepat dan sesuai dalam memperoleh data sebagai sumber dan bahan utama untuk menunjang dari pada hasil penelitian yang berkualitas. Dalam penelitian ini dilaksanakan utamanya dalam pengumpulan data tentang studi komparatif dan kontrastif nilai-nilai Fonologi antara Bahasa Arab dan Bahasa Indonesia bagi mahasiswa Program Studi Pendidikan Bahasa Arab UIN Sunan Ampel Surabaya.

\section{FGD}

${ }^{3}$ Sutrisno HadiMetode Researce(Jakarta : Bina Aksara, 1995), 64 
Group Discussion adalah suatu proses diskusi yang melibatkan para pakar (ahli) untuk mengidentifikasi masalah, analisis penyebab masalah, menentukan cara-cara penyelesaian masalah, dan mengusulkan berbagai alternatif pemecahan masalah dengan mempertimbangkan sumber daya yang tersedia. Dalam diskusi kelompok terjadi curah pendapat (brain storming) di antara para ahli dalam studi komparatif dan kontrastif nilai-nilai fonologi antara Bahasa Arab dan Bahasa Indonesia bagi mahasiswa Program Studi Pendidikan Bahasa Arab UIN Sunan Ampel Surabaya. Mereka mengutarakan pendapatnya sesuai dengan bidang keahlian masing-masing. ${ }^{4}$

Teknik ini digunakan untuk mengungkap permaknaan dari suatu kelompok berdasarkan hasil diskusi yang terpusat pada suatu permasalahan tertentu. FGD juga dimaksudkan untuk menghindari permaknaan yang salah dari seorang peneliti terhadap focus masalah yang sedang diteliti ${ }^{5}$ Teknik ini di gunakan sebagai bahan masukan untuk merevisi atau penyempurnaan produk baik produk terbatas, luas dan terakhir.Jadi penulis melakukan studi komparatif dan kontrastif nilai-nilai Fonologi antara Bahasa Arab dan Bahasa Indonesia bagi mahasiswa Program Studi Pendidikan Bahasa Arab UIN Sunan Ampel Surabaya dengan berdiskusi bersama para pakar atau ahli di bidang materi ilmu Aswat .

\section{Kuesioner}

Angket atau kuesioner merupakan suatu teknik pengumpulan data secara tidak langsung (peneliti tidak langsung bertanya jawab dengan responden). Instrumen atau alat pengumpulan datanya juga disebut angket berisi sejumlah pertanyaan-pertanyaan yang harus dijawab atau direspon oleh responden 6 . Responden mempunyai kebebasan untuk memberikan jawaban atau respon sesuai dengan persepsinya.

Teknik ini dilaksanakan utamanya dalam pengumpulan data dari mahasiswa tentang studi komparatif dan kontrastif nilai-nilai Fonologi antara Bahasa Arab dan Bahasa Indonesia bagi mahasiswa Program Studi Pendidikan Bahasa Arab UIN Sunan Ampel Surabaya

${ }^{4}$ Ibid., 20.

${ }^{5}$ H.B. Sutopo,Metodologi Penelitian Kualitatif(Surakarta : UNS Press, 2002).73

${ }^{6}$ H.B. Sutopo,Metodologi Penelitian Kualitatif 82 


\section{Teknik Analisis Data}

Analisis yang digunakan dalam penelitian ini menggunakan analisa data kualitatif. Sesuai dengan karakteristik penelitian yang dilakukan, data yang dihasilkan dari kuesioner dianalisis menggunakan teknik analisis deskriptif untuk melihat kecenderungan-kecenderungan yang terjadi. Sedangkan data yang bersifat kualitatif yang diperoleh dari hasil wawancara, focus group discussion (FGD), observasi dan dokumentasi, dianalisis dengan teknik analisis data kualitatif model interaktif yang secara simultan terdiri dari tahapan: (1) pengumpulan data, (2) Reduksi data, (3) penyajian data, (4) interpretasi, dan (5) penarikan kesimpulan/verifikasi.

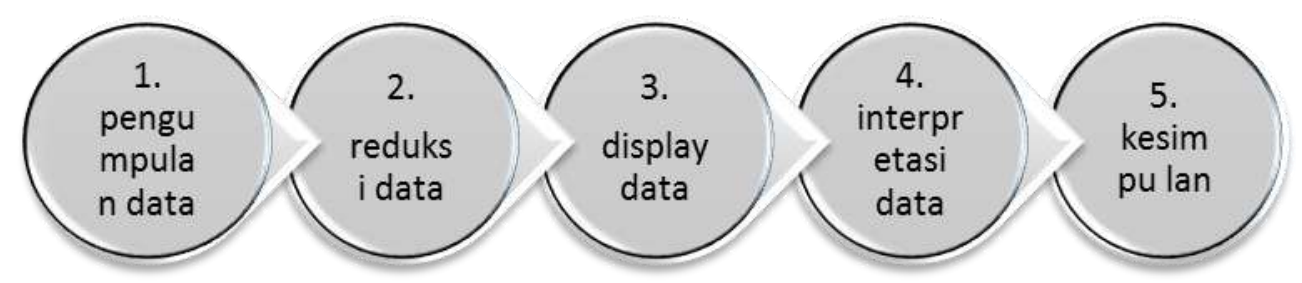

Gambar 3.11

Teknik Analisa Data Penelitian

Sebenarnya ada beragam tahapan dalam teknik analisis data ini, seperti yang ditawarkan oleh Lexy J. Moleong, yaitu dengan menelaah seluruh data yang tersedia dari berbagai sumber. Setelah dibaca, dipelajari dan ditelaah lalu mengadakan reduksi, penyajian dan penarikan simpulan. ${ }^{7}$

\footnotetext{
7 Tentang analisis data kualitatif ini baca selengkapnya dalam Lexy J. Moleong, Metodologi Penelitian Kualitatif (Bandung; PT Remaja Rosdakarya, 2001), 247.
} 


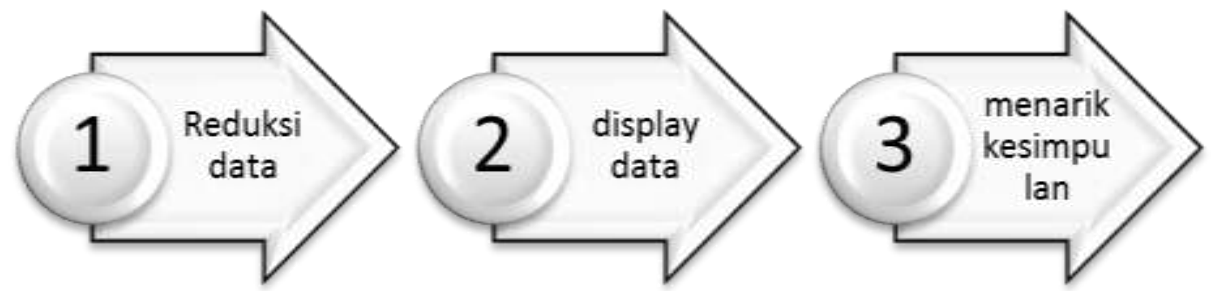

Gambar 3.12

Teknik Analisa Data Penelitian Moleong

Tak jauh dari Moleong, Sanaky juga merumuskan analisis data sebagai suatu rangkaian kegiatan yang dimulai dari reduksi data, display data, pemahaman/interpretasi/penafsiran, serta yang terakhir adalah mengambil kesimpulan. ${ }^{8}$

Penulis dalam penelitian ini mereduksi semua data yang berhubungan dengan studi komparatif dan kontrastif nilai-nilai Fonologi antara Bahasa Arab dan Bahasa Indonesia bagi mahasiswa Program Studi Pendidikan Bahasa Arab UIN Sunan Ampel Surabaya

Setelah mereduksi data yang masuk, peneliti mendisplay data yang dianggap relevan dan layak dalam penelitian ini. Setelah data terdisplay, penulis mencoba untuk memahami, menginterpretasi dan menafsirkan data untuk ditarik sebuah kesimpulan ke dalam penelitian ini sehingga menghasilkan sebuah studi komparatif dan kontrastif nilai-nilai Fonologi antara Bahasa Arab dan Bahasa Indonesia bagi mahasiswa Program Studi Pendidikan Bahasa Arab UIN Sunan Ampel Surabaya. Karena penelitian ini bersifat kualitatif, maka analisis data juga penulis lakukan sejak sebelum memasuki lapangan, selama di lapangan, dan setelah selesai di lapangan, sebagaimana yang digagas oleh Nasution. ${ }^{9}$

\section{Kerangka Teori}

\section{Konsep Dasar Fonologi atau Ilmus Aswat}

\footnotetext{
${ }^{8}$ Sanaky, Pengolahan dan Analisis Data, dalam http//: www.sanaky.com/ Materi IX.
}

${ }^{9}$ Sugiyono, Memahami Penelitian Kualitatif (Bandung : CV.Alvabeta, 2005), hal. 40. 


\section{Pengertian Fonologi}

Fonologi berasal dari bahasa Yunani yaitu phone = 'bunyi', logos = 'ilmu'. Secara harfiah, Secara etimologi kata fonologi berasal dari gabungan kata fon yang berarti bunyi, dan logi yang berarti ilmu. Sebagai sebuah ilmu, fonologi lazim diartikan sebagai bagian dari kajian linguistik yang mempelajari, membahas, membicarakan, dan menganalisis bunyi-bunyi bahasa yang diproduksi oleh alatalat ucap manusia10.

\section{Dasar Klasifikasi Bunyi Bahasa Indonesia dan Bahasa Arab}

Fonologi adalah bunyi-bunyi bahasa sebagai satuan terkecil dari ujaran beserta dengan "gabungan" antar bunyi yang membentuk silabel atau suku kata serta juga dengan unsur-unsur suprasegmentalnya, seperti tekanan, nada, hentian dan durasi ${ }^{11}$ Bunyi-bunyi bahasa ketika diucapkan ada yang bisa disegmensegmenkan, diruas-ruaskan, dan dipisah-pisahkan. Bunyi-bunyi yang bisa disegmentasikan ini disebut bunyi segmental. Tetapi ada juga yang tidak bisa disegmentasikan karena kehadiran bunyi ini selalu mengiringi, menindih, atau menemani bunyi segmental. Bunyi ini disebut bunyi suprasegmental.12

\section{Bunyi segmental}

Klasifikasi bunyi segmental didasarkan berbagai macam kriteria, yaitu: 1 . Ada tidaknya gangguan, 2. Mekanisme udara, 3. Arah udara, 4. Pita suara, 5. Lubang lewatan udara, 6. Mekanisme artikulasi, 7. Cara gangguan, 8. Maju mundurnya lidah, 9. Tinggi rendahnya lidah 10. bentuk bibir ${ }^{13}$.

\section{Bunyi suprasegmental}

\footnotetext{
10 Pateda, Mansoer,. Linguistik sebuah pengantar, (Bandung, Angkasa, 1990) hal. 33

11 Masnur Muslich, 2008, Fonologi bahasa indonesia tinjauan deskriptif sistem bunyi bahasa Indonesia, jakarta; hal 05

12 Masnur Muslich, 2008, Fonologi bahasa indonesia tinjauan deskriptif sistem bunyi bahasa Indonesia, jakarta; hal. 61

13 Ibid, hal 46
} 
Oleh para fonetisi, bunyi-bunyi suprasegmental ini dikelompokkan menjadi empat jenis, yaitu menyangkut aspek:

\section{Tinggi rendah bunyi التنغيم (nada)}

$$
\begin{aligned}
& \text { التنغيم : نغمة الصوت هي احدى صفاته , وكثيراما تكون عامل حها في اداء المعنى , }
\end{aligned}
$$

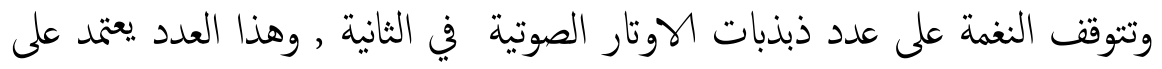

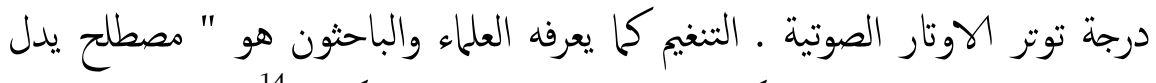

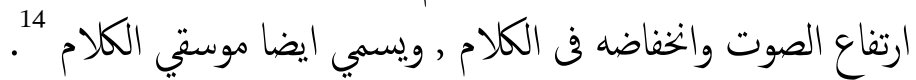

Menurut ahmad mukhtar amir (220: 1990) mengatakan bahwa perbedaan antara nada dan intonasi yaitu, Nada adalah tingkatan bunyi atau tingkatantingkatannya terhadap kata atau di sebut dengan word tone. Sedangkan intonasi adalah tingkatan bunyi terhadap kalimat, ungkapan atau kumpulan-kumpulan kalimat.

Nada biasa disebut dengan ' tone, tingkatan bunyi' fonem diatas suku kata yang berbarengan dengan fonem suku kata dan dapat mempengaruhi pada makna atau dapat merubah makna.

Tingkatan nada dalam bahasa: (1). Nada rendah atau ringan rumus ponemnya (1) contoh: 1جاء الأستاد, (2). Nada sedang atau datar rumus ponemnya

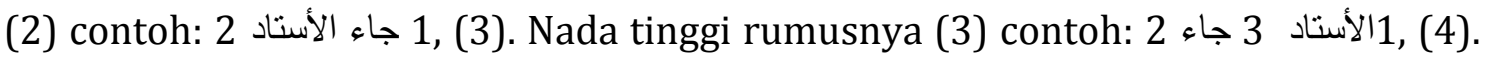
Nada sangat tinggi rumusnya (4) contoh: 4

Intonasi adalah sebuah unsure dalam ucapan yang dapat membantu seseorang untuk mengekspresikan sesuatu yang terdapat dalam hati dan perasaannya. Yang terjadi dengan naik turunnya suara. Intonasi dalam banyak hal mempunyai fungsi kebahasaan yang sangat penting, dengan intonasi makna suatu kalimat dapat berbeda.

Intonasi dapat terjadi dalam perpindahan dari suatu bunyi ke bunyi yang lain, sebagaimana terjadi dalam perpindahan dari kalimat ke kalimat lain dengan naik, turun atau samanya intonasi suara disbanding dengan suara yang sebelum atau sesudahnya.

Intonasi dalam berbagai tingkatan:

\footnotetext{
14 Masnur Muslich, 2008, Fonologi bahasa r 14 الدكنور نصر الدين ادريس جوهر . علم الأصوات لدراسي اللغة العربية من الاندونيسيين 14 Ibid, hal 46 indonesia tinjauan deskriptif sistem bunyi bahasa Indonesia, jakarta; 61
} 
Tingkatan pertama adalah Alur 231 yaitu intonasi pada kalimat tertentu yang mengandung kalimat Tanya dan tidak bisa terjawab oleh "ya" atau "tidak". Contoh : 2 muhammad 3 tidak ada 1.

Tingkatan kedua adalah Alur 233 yaitu intonasi pada kalimat tertentu yang mengandung kalimat Tanya dan bisa terjawab oleh "ya" atau "tidak". Contoh : 2 muhammad 3 pergi 3 ? .

Tingkatan ketiga adalah Alur 244 yaitu intonasi yang menunjukan makna takjub atau heran. Contoh: 2 Ahmad 4 mati 4.

Intonasi mempunyai banyak fungsi kebahasaan. Diantaranya ada yang bersifat umum, berlaku untuk semua bahasa, sebagian lainnya bersifat khusus yang hanya berlaku untuk bahasa tertentu saja. Diantara fungsi kebahasaan dari intonasi adalah sebagai berikut:

\section{Fungsi semantik}

Fungsi semantik yang membedakan arti dari suatu kata atau kalimat. Suatu kata atau kalimat jika dituturkan dengan intonasi yang berbeda dapat berdampak pada arti yang berbeda pula. Seperti kata "Astagfirullah" jika dituturkan dengan intonasi menurun artinya adalah minta ampun kepada Allah. Tetapi jika dituturkan engan naik, turun, naik maka bias berarti omelan, karena tidak mengikuti aturan.

\section{Fungsi ketatabahasaan}

Fungsi ketatabahasaan yang membedakan bentuk-bentuk kalimat. Suatu kalimat jika dituturkan dengan intonasi yang berbeda dapat merubah bentuknya dari kalimat berita menjadi kalimat seru atau Tanya. Contoh “وصل القطار" jika dituturkan dengan intonasi mendatar akan menjadi kalimat berita, dan jika dituturkan dengan intonasi naik maka merupakan kalimat Tanya. Sedangkan apabila dituturkan dengan intonasi naik turun maka kalimat tersebut menjadi kalimat takjub atau heran.

\section{Fungsi ekspresi kejiwaan}

Fungsi ekspresi kejiwaan menunjukan sikap kejiwaan penutur. Seperti kalimat: “قد كسرت الباب مرة اخرى" apabila dituturkan dengan intonasi biasa kalimat tersebut berarti "saya tidak mengerti maksudmu, coba ulangi ucapan anda" dan apabila dituturkan dengan intonasi naik maka akan berarti persetujuan dan menguatkan pengertian. Dan jika naik turun berarti heran atau takjub. 


\section{Keras-lemah bunyi البر (tekanan)}

$$
\text { من مقاطع الكلمة بصورة أوضح و أجلى العربية معناه البروز و الظهور و عرّف كمال بشر النبر بأنه نطق مقطع بقية المقاطع التى تجاوره } 15
$$

\section{Kesenyapan المفصل (jeda) ${ }^{16}$.}

$$
\begin{aligned}
& \text { المفصل هو سكتة خفيفة بين كلمات او مقاطع في حدث كلامي بقصد الدلالة علي مكان } \\
& \text { انتهاء لفظ ما او مقاطع ما و بداية اخر. }
\end{aligned}
$$

Tekanan dan jeda dalam bahasa Arab sangat penting karena tekanan dan jeda dapat mengubah makna kalimat. Seperti tampak pada contoh:

\# buku // sejarah / baru \#

\# buku / sejarah // baru \#

Kalimat pertama bermakna "buku mengenai sejarah baru", sedangkan kalimat kedua bermakna "buku baru mengenai sejarah".

$$
\text { وما يعلم تأويله إلا اللهيو الر اسخون في العلم يقولون آمنا به ( آل عمر ان: V ) }
$$

"Padahal tidak ada yang mengetahui takwilnya kecuali Allah.

Dan orang-orang yang ilmunya mendalam berkata, "Kami beriman kepadanya (Al-Qur'an)".

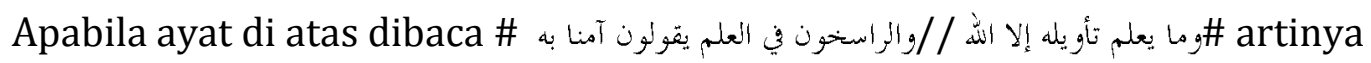
tidak ada yang mengetahui mengenai ayat-ayat mutasyabihat kecuali Allah semata.

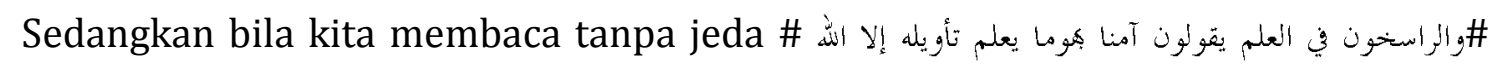
artinya Allah dan orang-orang yang ilmunya mendalam mengetahui ayat-ayat mutasyabihat.

\section{Mekanisme Artikulasi Bahasa Indonesia dan Bahasa Arab}

Mekanisme artikulasi adalah alat ucap mana yang bekerja atau bergerak ketika menghasilkan bunyi bahasa. Berdasarkan kriteria ini, bunyi dapat dikelompokkan sebagai berikut: 1)Bilabial (Syafatniyah), 2)Labio-dental

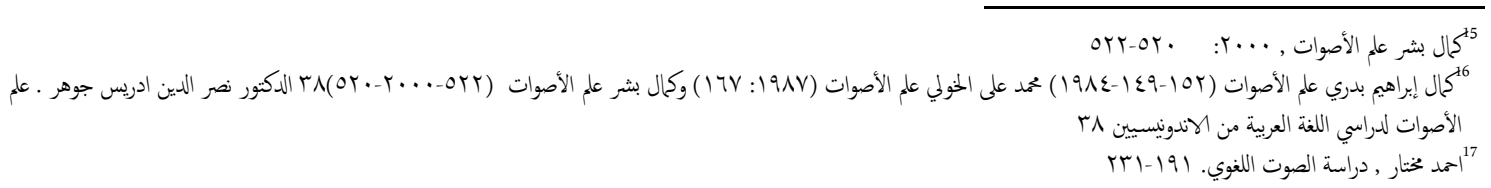


(Syafahiyah Asnaniyah), 3)Inter-dentals (Baina Asnaniyah), 4)Apico-alveolars (Zalqi Lasawi), 5)Apico-denal-alveolars (Zalqi Lasawi Asnani), 6)Fronto-palatals (Tarfi Gari), 7)Medio patatals (wasti Gari), 8)Dorso Velars (Qusa Tabaqi), 9)DorsoUvulars (Qusa Lasawi), 10)Root-Pharyngeals (Jazari Halqi), 11)Glottals (Hanjari) ${ }^{18}$ Tempat keluarnya huruf, yaitu

1.

2.

3.

4.

5.

6.

7. Blade of Tongue

8. Front of Tongue

9. Back of Tongue
10.

11.

12.

13. Tip of Tongue

14.

Pharynx

Epiglottis

Position of Vocal

Cords

$15 . \quad$ Windpipe

f)

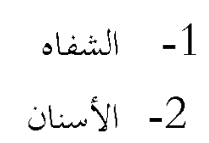

3- 2- أصوز الأنيان

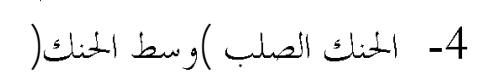

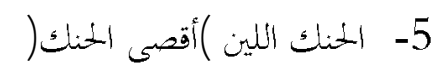

-6 - اللهاة

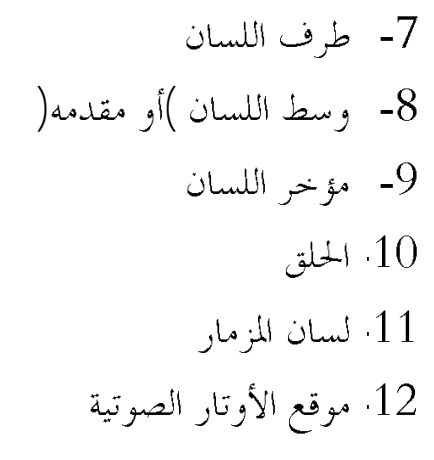

13. ذلق اللسان )غايتها

14. منطقة الحنجرية )من الأمانم)

15. القصبة الهو ائية (19)

Selain pembahasan diatas dalam fonologi juga di bahas tentang Asimilasi dan Desimilasi

\section{Asimilasi (الماثلة)}

Menuruat bahasa asimilasi ialah "persamaan” atau "kias” (analogi).

Sebagian ahli bahasa mendefinisikan asimilasi ialah perubahan yang

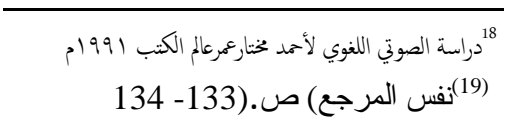


terhimpun dalam bunyi, karena adanya kedekatan bunyi yang disebabkan oleh bunyi yang lain. Pendapat yang lain mendefinisikan bahwa asimilasi adalah "memalingkan bunyi yang berbeda menjadi bunyi yang sama, baik sebagian atau keseluruhan. Menurut Laver, asimilasi adalah saling berpengaruhnya antar bunyi mengakibatkan ciri bunyi yang dipengaruhi menjadi berubah untuk menyesuaikan dengan bunyi yang mempengaruhi.

Menurut Abercrombie (1974: 133-139) asimilasi dapat terjadi berdasarkan tiga faktor: getaran pita suara, pergerakan velum, perpindahan daerah artikulasi. Asimilasi yang berdasarkan getaran pita suara dapat mengakibatkan bunyi tak bersuara (mahmus) menjadi bersuara (majhur) atau sebalikanya, seperti:

Dari contoh di atas terdapat asimilasi (ت) dengan (د), tapi selain perubahan (ت) menjadi (د) dalam proses tersebut juga terjadi pelepasan vocal. Jadi peroses asimilasi tersebut sebagai berikut:

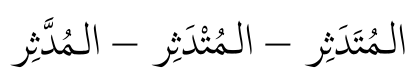

Asimilasi yang melibatkan pergerakan velum akan mengakibatkan bunyi non-nasal menjadi berciri nasal, contoh :

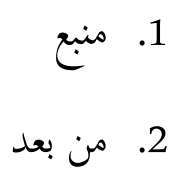

Pada kedua contoh di atas (ب) yang asalnya berciri non-nasal menjadi berciri nasal karena terpengaruh oleh (ن). 
Pertanyaan yang harus ada dalam kajian asimilasi ini ialah sebagai berikut:

1. Apakah asimilasi itu progresif ketika adanya pengaruh yang sebelumnya terhadap yang sesudahnya. Contoh: menukar ta') ifti'al (تفتل) menjadi dal(د) setelah zai(j) dalam contoh ازدجر, aslinya ialah ازتجر. Menjelaskan ta' (ت) yang dipengaruhi oleh Zai (j) yang dijaharkan, maka dipalingkan menjadi penukarnya yang dijaharkan yaitu dal (د). Apakah asimilasi itu bersifat regresif ketika ada pengaruh dari yang sesudahnya terhadap yang sebelumnya, contohnya menukar fa ifti'al (ف الإفتعال) apabila ada

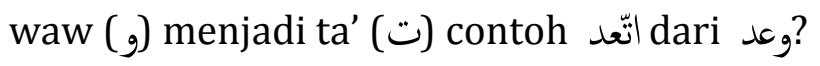

2. Apakah asimilasi itu antara bunyi yang berdekatan (contigious) seperti contoh sebelumnya, yang dinamakan dengan asimilasi yang berdekatan (contact assimilation). Atau apakah asimilasi itu antara bunyi yang berjauhan (noncontiguous), seperti menebalkan sin (س) سراط و pada karena pengaruh tha (b) yang ditebalkan. Asimilasi ini dinamakan dengan asimilasi berjauhan (distant assimilation)?

3. Apakah asimilasi itu sebagian saja, ketika bunyi tersebut tidak sesuai dengan yang lainnya. Misalnya انبعث, yang mana nun (ن) yang diucapkan di sini ialah mim (م) karena pengaruh ba' (ب) syafawi (maka hasilnya: ن

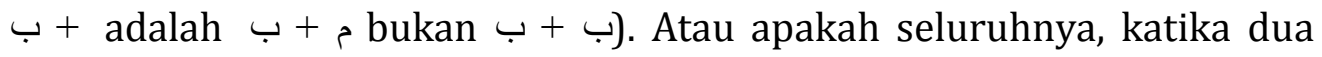
bunyi itu sesuai?

4. Apakah asimilasi itu dari sisi tempat keluar huruf ataukah dari sisi cara pengucapannya.

\section{Asimilasi Progressif dan Regresif}

Berdasarkan urutan atau alur bunyi yang mempengaruhi asimilasi dalam bahasa Arab dibagi menjadi dua, yaitu 
1. Asimilasi progresif adalah proses berpengaruhnya sebuah bunyi pada bunyi sesudahnya, seperti ازدهر ازتهر berasal darimana bunyi tak bersuara ( $(ت)$ merubah menjadi bersuara ( $)$ karena terpengaruh oleh sifat bunyi $(j)$ yang bersuara.

2. Asimilasi regresif adalah proses berpengaruhnya sebuah bunyi pada bunyi sebelumnya, seperti السّلام menjadi الس (ال) dimana konsonan dipengaruhi oleh bunyi (س) dalam hal ini Syahin menegaskan bahwa asimilasi regresif dalam bahasa Arab lebih produktif dari asimilasi progresif.

\section{Asimilasi Dilihat Dari Aspek Tempat Keluar Huruf}

Apabila asimilasi itu sampai pada keberadaan dua bunyi dalam satu makhraj maka persamaan tersebut adalah dari sisi tempat keluar hurufnya (makhrajnya). Misalnya, امبعث أو امبرى keduanya diucapkan أبعث أو انبرى dengan menukar bunyi nun (ن) dari makhrajnya yang asli ke makhraj ba'(ب) dipalingkan menjadi mim (م) karena pengaruh ba' (ب). Seperti itu juga dengan lam ta'rif (لام التعريف) kepada ta' (ت) paka pada contoh التعليم. Maka asimilasi ini sampai kepada penukaran bunyi dari yang aslinya menjadi yang mempengaruhinya. Contoh lainnya ialah: الثوب و السلامة و الثجر وإحخ.

Adapun apabila bunyi tidak tertukar dari tempat keluarnya (makhraj) maka persamaan ini ialah dari segi cara pengucapannya. Misalnya, سراطyang ditukar menjadi ادتخر ditukar menjadi صراط atau ادخر.

Demikian juga ketika bunyi letupan (infijar) mengikuti bunyi hidung (dengung), maka bunyi letupan tersebut diambil cara pengucapannya dari hidung. Misalnya pada kata لكنة و يضنى و بتنا. Seiringan dengan contoh tersebut juga bunyi pantulan (Qalqalah) yaitu قطبجد, Apabila pembicara belum mengkaji yang diikutinya dengan bunyi pantulan. 
Apabila bunyi letupan mengikuti bunyi yang lunak, maka bunyi letupan ini terlepas dari hal tersebut. Misalnya يتلو و .كKح.

Apabila sampai pengaruh asimilasi itu pada penukaran bunyi dari fonemnya yang muncul pada bunyi tersebut menjadi fonem yang lain, maka perubahan ini menjadi bagian yang tertukar. Misalnya, apabila bunyi nun (ن) ditukar menjadi mim (م) karena pengaruh ba' (ب) pada kata (برى ) Ini adalah bunyi yang terjadi pada tempat yang lain dari nun (ن). Misalnya: مال و نال

\section{Disimilasi (المخالفة )}

Disimilasi merupakan lawan dari Asimilasi, karena perubahan bunyi yang ada dalam urutan perkataan disebabkan adanya pengaruh bunyi yang berdekatan. Akan tetapi, perubahan yang berlawanan ini menjadi bertambah ketika ada perbedaan antara dua bunyi. Disimilasi adalah fenomena yang lebih sedikit terjadi pada bunyi daripada asimilasi.

Disimilasi merupakan fenomena yang ada pada setiap bahasa. Misalnya dalam bahasa Inggris, kata "Marble" dan "Pilgrim". Kedua kata tersebut asalnya adalah "Malble" dan "Pilglim", yakni (l) yang diganti dengan (r). Hurwitz mengansumsikan bahwa kata-kata bahasa Arab sebagian besar yang terdiri dari "ra", "lam", "nun", atau "mim" telah menghasilkan pengaruh disimilasi antara dua bunyi yang sama. Sebagaimana dapat kita lihat pada

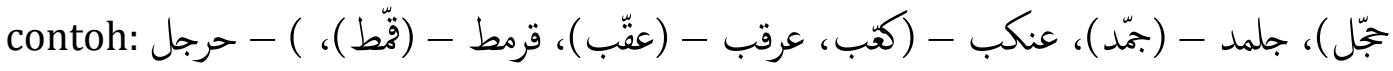

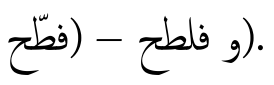

1. Menukar fathah menjadi kasrah ketika berdekatan dengan alif. Tujuannya ialah menghindari pengucapan dari harkat-harkat tertentu. Penjelasan ini menjelaskan kenapa jama' mu'annats salim itu di-nashab-kan dengan 
kasrah dan nun mutsanna itu di-kasrah-kan yang berlawanan dengan jama' mudzakkar salim yang di-fathah-kan.

2. Menukar kasrah dengan fathah apabila berdekatan dengan ya' mad. Sebagaimana kebanyakan terdapat dalam bahasa Arab Amiyah yang mana

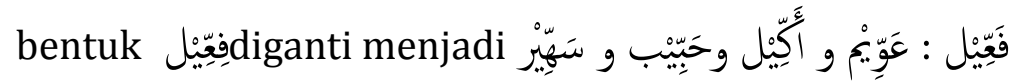

3. Mengganti dhammah yang berurutan dengan dhammah + fathah.

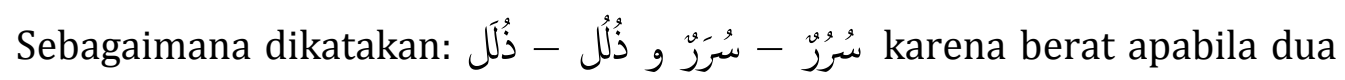
dhammah di-mudha'af-kan.

\section{HASIL TEMUAN DAN PEMBAHASAN}

\section{Studi komparatif nilai-nilai fonologi antara Bahasa Bahasa Arab dan Bahasa Indonesia} الأصوات المتائلة أو المثطابقة فن اللغتين:

Suara dalam kedua bahasa Arab Atau Indonesia di mungkinkan sifatnya identik ( sama persis )

هناك أصوات في اللغتين يمكن وصفها بأهها متثاثلة أو متطابقة sama persis )لما لها من سهات صوتية مشتركة سواء كانت من حيث المخرج أو من حيث الصفة، وني وصني

Suara dalam kedua bahasa Arab Atau Indonesia di mungkinkan sifatnya identik atau sama baik dari segi tempat keluarnya suara atau sifatnya.

\begin{tabular}{|c|c|c|}
\hline الوصف & الأصوات & الرق \\
\hline \multirow{2}{*}{$\begin{aligned} \text { Bilabial, hambat, bersuara } \\
\text { كلاهـا شفتاني، انفجاري، مجهور }\end{aligned}$} & ب & \multirow{2}{*}{1} \\
\hline & B & \\
\hline \multirow{2}{*}{ Bilabial, nasal, bersuara } & $p$ & \multirow{2}{*}{2} \\
\hline & $\mathrm{M}$ & \\
\hline \multirow{2}{*}{ Bilabial, semi-vokal } & 9 & \multirow{2}{*}{3} \\
\hline & $\mathrm{w}$ & \\
\hline \multirow{2}{*}{$\begin{array}{l}\text { كلاهما شفتي-أسناني، احتكلكي، عموس/ } \\
\text { Labio-dental, geseran, tak bersuara }\end{array}$} & ف & \multirow{2}{*}{4} \\
\hline & $\mathrm{F}$ & \\
\hline \multirow{2}{*}{ 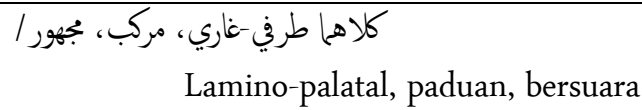 } & ? & \multirow{2}{*}{5} \\
\hline & $\mathrm{J}$ & \\
\hline \multirow{2}{*}{$\begin{array}{l}\text { كلاهـا قصي-طبتي، انقجاري، محموس/ } \\
\text { Dorso-velar, hambat, tak bersuara }\end{array}$} & S & \multirow{2}{*}{6} \\
\hline & $\mathrm{K}$ & \\
\hline \multirow{2}{*}{$\begin{aligned} \text { / كلاها ذلقي -ثوي، تكراري، مجهور } \\
\text { Apiko-alveolar, getar, bersuara }\end{aligned}$} & ر & \multirow{2}{*}{7} \\
\hline & $\mathrm{R}$ & \\
\hline
\end{tabular}




\begin{tabular}{|c|c|c|}
\hline \multirow{2}{*}{$\begin{array}{l}\text { كلاهـا ذلقي -لثوي، احتكلكي مجهور / } \\
\text { Apiko-alveolar, geseran, tak bersuara }\end{array}$} & $j$ & \multirow{2}{*}{8} \\
\hline & $\mathrm{Z}$ & \\
\hline \multirow{2}{*}{$\begin{array}{l}\text { كلاها ذلقي - لثوي - احتككي - مهموس/ } \\
\text { Apiko-alveolar, geseran, tak bersuara }\end{array}$} & س & \multirow[t]{2}{*}{9} \\
\hline & $\mathrm{S}$ & \\
\hline \multirow{2}{*}{$\begin{array}{l}\text { كلاها حنجري-|حتكاكي-مموس } \\
\text { Glottal (laringal), geseran, tak bersuara }\end{array}$} & هـ & \multirow{2}{*}{10} \\
\hline & $\mathrm{H}$ & \\
\hline
\end{tabular}

\section{الأصوات المتشابهة في اللغتين}

Suara dalam kedua bahasa Arab Atau Indonesia di mungkinkan sifatnya mirip هناك أصوات في اللغتين بمكن وصفها بأها متشابهة (mirip) إذا أنها تتماثل و تتطابق في جميع السمات الصوتية

$$
\text { إلا في سمة واحدة، و هي }
$$

Suara dalam kedua bahasa Arab Atau Indonesia di mungkinkan sifatnya mirip dari segi tempat keluarnya suara atau sifatnya.

\begin{tabular}{|c|c|c|c|c|}
\hline \multicolumn{3}{|c|}{ } & \multirow{2}{*}{$\begin{array}{c}\text { / Suara } \\
\end{array}$} & \multirow{3}{*}{$\begin{array}{c}\begin{array}{c}\text { الر } \\
\text { /Nmr }\end{array} \\
1\end{array}$} \\
\hline $\begin{array}{l}\text { bموس tak } \\
\text { bersuara }\end{array}$ & $\begin{array}{l}\text { انفجاري letupan/ } \\
\text { hambatan }\end{array}$ & $\begin{array}{c}\text { Apiko- } \text { ذلقي - لثوي - أسناني } \\
\text { alveolar, -dental }\end{array}$ & & \\
\hline $\begin{array}{l}\text { معموس tak } \\
\text { bersuara }\end{array}$ & $\begin{array}{l}\text { انفجاري letupan/ } \\
\text { hambatan }\end{array}$ & Apiko-alveolar, ذلقي - لثوي & $\mathrm{T}$ & \\
\hline بجهور bersuara & $\begin{array}{l}\text { hambatan } \\
\text { hat letupan/ }\end{array}$ & $\begin{array}{c}\text { ذلقي - لثوي - أسناني Apiko- } \\
\text { alveolar, -dental }\end{array}$ & 3 & .2 \\
\hline bجمهورbersuara & $\begin{array}{l}\text { انفجاري letupan/ } \\
\text { hambatan }\end{array}$ & Apiko-alveolar, & $\mathrm{D}$ & \\
\hline Pجمورbersuara & nasal & $\begin{array}{c}\text { ذلقي - لثوي - أسناني Apiko- } \\
\text { alveolar, -dental }\end{array}$ & ن ن & .3 \\
\hline Pجمورbersuara & nasal أنفي & Apiko-alveolar, ذلقي - لثوي & $\mathrm{N}$ & \\
\hline Pجهورbersuara & lateral جانبي la & $\begin{array}{c}\text { Apiko- } ذ \text { ذلقي - لثوي - أسناني } \\
\text { alveolar, -dental }\end{array}$ & J & .4 \\
\hline مجهورbersuara & lateral & Apiko-alveolar, ذلقي - لثوي & $\mathrm{L}$ & \\
\hline ف حركة & mi-vokal & centro-palatals وسطي - غاري & ي & .5 \\
\hline ف فركة & mi-vokal & centro-palatals وسطي - غاري & $\mathrm{Y}$ & \\
\hline مجهورbersuara & احتكالكي geseran & darso-velars قصي - طبقي & $\dot{\varepsilon}$ & .6 \\
\hline مجهورbersuara & انفجاري & darso-velarsS & G & \\
\hline $\begin{array}{l}\text { cمak tak } \\
\text { bersuara }\end{array}$ & احتك geseran & حلقي pharyngeals & 乙 & .7 \\
\hline
\end{tabular}

نصر الدين إدريس جوهر، علم الأصوات، سنة 10 .Y. ص VY 


\begin{tabular}{|c|c|c|c|c|}
\hline $\begin{array}{l}\text { bersuara } \\
\text { bموس tak }\end{array}$ & احتكالكي geseran & glottals حنجري & $\mathrm{H}$ & \\
\hline $\begin{array}{l}\text { bersuara } \\
\text { bark tak }\end{array}$ & احتكلكي geseran & darso-velars قصي - طبقي & $\dot{\tau}$ & \multirow[t]{2}{*}{.8} \\
\hline $\begin{array}{l}\text { borsuara } \\
\text { bers tak }\end{array}$ & $\begin{array}{l}\text { hambatan } \\
\text { hat letupan/ }\end{array}$ & darso-velars قصي - طبقي & $\mathrm{K}$ & \\
\hline $\begin{array}{l}\text { 'مموس tak } \\
\text { bersuara }\end{array}$ & $\begin{array}{l}\text { hambatan } \\
\text { hatetupan/ }\end{array}$ & darso-velars قصي - طبقي & ق & \multirow[t]{2}{*}{.9} \\
\hline $\begin{array}{l}\text { bak tak } \\
\text { bersuara }\end{array}$ & $\begin{array}{l}\text { hambatan } \\
\text { hat letupan/ }\end{array}$ & darso-velars قصي - طبقي & $\mathrm{K}$ & \\
\hline $\begin{array}{l}\text { bersuara } \\
\text { bat tak } \\
\end{array}$ & احت geseran & franto-platals طرفي - غاري & ش & \multirow[t]{2}{*}{.10} \\
\hline $\begin{array}{l}\text { كموس tak } \\
\text { bersuara }\end{array}$ & احتكلكي geseran & Apiko-alveolar, ذلقي - ثلوي & $\mathrm{S}$ & \\
\hline $\begin{array}{l}\text { tak } \\
\text { bersuara }\end{array}$ & احتكلكي geseran & interdentals بين أسناني & $\dot{H}$ & \multirow[t]{2}{*}{.11} \\
\hline $\begin{array}{l}\text { bersuara } \\
\text { bموس tak }\end{array}$ & احتكاكي geseran & Apiko-alveolar, ذلقي - ثلوي & $\mathrm{S}$ & \\
\hline مجوط:bersuara & احتكاح geseran & interdentals بين أسناني & $\dot{j}$ & \multirow[t]{2}{*}{.12} \\
\hline بجهورbersuara & احتكاحك geseran & ذذلقي - لثوي Apiko-alveolar, & $\mathrm{Z}$ & \\
\hline $\begin{array}{l}\text { كموس tak } \\
\text { bersuara }\end{array}$ & احتكلكي geseran & $\begin{array}{c}\text { ذلقي - لثوي / Apiko- } \\
\text { alveolar, }\end{array}$ & ص & \multirow[t]{2}{*}{.13} \\
\hline $\begin{array}{l}\text { tak } \\
\text { baموس tarsuara }\end{array}$ & احتكاحك geseran & $\begin{array}{c}\text { ذلقي - لثوي/ Apiko- } \\
\text { alveolar, }\end{array}$ & $\mathrm{S}$ & \\
\hline
\end{tabular}

\section{Studi kontrastif nilai-nilai fonologi antara Bahasa Arab dan Bahasa :}

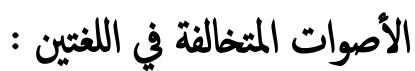

Suara dalam kedua bahasa Arab Atau Indonesia di mungkinkan sifatnya berbeda أصوات فى اللغتين يمكن و صفها بأنها متخالفة لما بننها من اختلافات في السمات الصوتية سواء كانت من حيث المخرج أو من حيث الصفة، و هي: Suara dalam kedua bahasa Arab Atau Indonesia di mungkinkan sifatnya berbeda baik dari segi tempat keluarnya suara atau sifatnya.

\begin{tabular}{|c|c|c|c|c|c|}
\hline \multicolumn{4}{|c|}{ الوصاف } & الأصوات & الرق \\
\hline $\begin{array}{c}\text { مطبق } \\
\text { terkatup }\end{array}$ & مجهور bersuara & $\begin{array}{c}\text { hambatan } \\
\text { hatupan/ }\end{array}$ & ذلقي_-ثوي_أسناني & ض & .1 \\
\hline
\end{tabular}




\begin{tabular}{|c|c|c|c|c|c|}
\hline & & & interdentals & & \\
\hline Lرق tipis & طجهورbersuara & $\begin{array}{l}\text { hambatan } \\
\text { hatupan/ }\end{array}$ & $\begin{array}{l}\text { ذلتي-ثثوي } \\
\text { Apiko- } \\
\text { alveolar, }\end{array}$ & $\mathrm{D}$ & \\
\hline $\begin{array}{c}\text { مطبق } \\
\text { terkatup }\end{array}$ & مجهور bersuara & احتكلى geseran & $\begin{array}{c}\text { بين أسنانية } \\
\text { interdentals }\end{array}$ & b - & \multirow[b]{2}{*}{.2} \\
\hline مرقق tipis & مجهور bersuara & $\begin{array}{c}\text { hambatan } \\
\text { hatupan/ }\end{array}$ & $\begin{array}{l}\text { ذلقي-ثنوي } \\
\text { Apiko- } \\
\text { alveolar, }\end{array}$ & $\mathrm{D}$ & \\
\hline $\begin{array}{c}\text { مطبق } \\
\text { terkatup }\end{array}$ & مجمهور bersuara & احتكلكى geseran & $\begin{array}{c}\text { بين أسنانية } \\
\text { interdentals }\end{array}$ & ظ - & \multirow[b]{2}{*}{.3} \\
\hline tipis مرقق tis & بجمور bersuara & احتكلى geseran & $\begin{array}{l}\text { ذلتي-ثوي } \\
\text { Apiko- } \\
\text { alveolar, }\end{array}$ & $\mathrm{Z}$ & \\
\hline $\begin{array}{c}\text { مطبق } \\
\text { terkatup }\end{array}$ & $\begin{array}{l}\text { sorsuara } \\
\text { bagk }\end{array}$ & $\begin{array}{c}\text { hambatan } \\
\text { hatupan/ }\end{array}$ & $\begin{array}{c}\text { ذلتي-لثوي-أسناني- } \\
\text { Apiko- } \\
\text { alveolar- } \\
\text { dental }\end{array}$ & $b$ & \multirow[t]{2}{*}{.4} \\
\hline مرقق tipis & $\begin{array}{l}\text { bersuara } \\
\text { كموس tak }\end{array}$ & $\begin{array}{c}\text { hambatan } \\
\text { hamban/ letupan }\end{array}$ & $\begin{array}{l}\text { ذلقي-ثوي } \\
\text { Apiko- } \\
\text { alveolar, }\end{array}$ & $\mathrm{T}$ & \\
\hline - & $\begin{array}{l}\text { tak } \\
\text { bersuara }\end{array}$ & l geseran & $\begin{array}{c}\text { قصي-طبقي } \\
\text { darso-velars }\end{array}$ & $\dot{\tau}$ & \multirow{2}{*}{.5} \\
\hline - & $\begin{array}{l}\text { borsuara } \\
\text { bers }\end{array}$ & احتكلى geseran & glottals & $\mathrm{H}$ & \\
\hline
\end{tabular}

\section{الأصوات العربية التي ليس لها مقابل في اللغة الإندونيسية، وهي:}

Suara Bahasa Arab ada yang tidak sesuai dengan suara Bahasa Indonesia

\begin{tabular}{|c|c|c|}
\hline الوصف ( الوف & 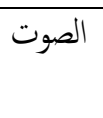 & $\begin{array}{l}\text { الر户 } \\
/ \mathrm{Nmr}\end{array}$ \\
\hline $\begin{array}{r}\text { interdentals- pharyngeals- geseran- } \\
\text { tak bersuara }\end{array}$ & $\dot{H}$ & 1 \\
\hline $\begin{array}{r}\text { rooto- pharyngeals- geseran- tak } \\
\text { bersuara }\end{array}$ & 乙 & r \\
\hline darso-velars- geseran- tak bersuara قصي - طبتي، احتكاكي، كموس & $\dot{\tau}$ & $r$ \\
\hline interdentals- geseran- bersuara بين أسناني - احتككي، مجهور & j & $\varepsilon$ \\
\hline Lamino-palatal- geseran- tak bersuara طرفي - غاري، احتككي، كموس & ش & 0 \\
\hline $\begin{array}{r}\text { Apiko-alveolar- geseran- tak } \\
\text { bersuara- terkatup }\end{array}$ & ص & 7 \\
\hline
\end{tabular}




\begin{tabular}{|c|c|c|}
\hline 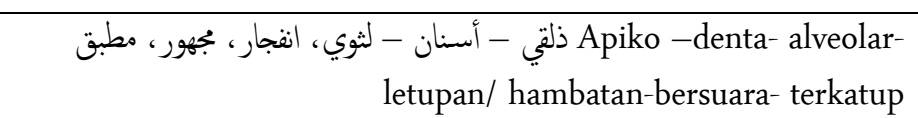 & ض & V \\
\hline 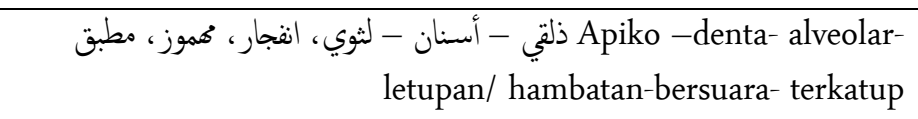 & $b$ & $\wedge$ \\
\hline $\begin{array}{r}\text { interdentals- geseran- bersuara- } \\
\text { terkatup }\end{array}$ & b & 9 \\
\hline glottals- pharyngeals- geseran- bersuara جذري - حلقي، احتككي، بجهور & $\varepsilon$ & 1. \\
\hline darso-velars- geseran- bersuara & $\dot{\varepsilon}$ & 11 \\
\hline قصي - لهوي، انفجاري، كموس & ق & Tr \\
\hline
\end{tabular}

\section{الأصوات الإندونيسة التي ليس لها مقابل في اللغة العربية':}

Suara Bahasa Indonesia ada yang tidak sesuai dengan suara Bahasa Arab

\begin{tabular}{|c|c|c|}
\hline & 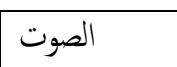 & الرق \\
\hline صوت شفوي، انفجاري، مجهور، كمافي "papa" & $\mathrm{P}$ & 1 \\
\hline صوت الطرفي غاري، مركب، كموس، كما في "cucu" & $\mathrm{C}$ & r \\
\hline صائت أو حركة كما في "beli" & $\mathrm{E}$ & $r$ \\
\hline صائت أو حركة كما في "toko" & $\mathrm{O}$ & $\varepsilon$ \\
\hline ط nرفي - غاري، أنفي، مجهور، برمز ب[ ńala] "nyala" كما في & $\mathrm{Ny}$ & 0 \\
\hline 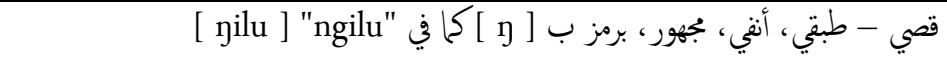 & $\mathrm{Ng}$ & 7 \\
\hline صائت ثنائي كما في "gulai" & $\mathrm{Ai}$ & $\checkmark$ \\
\hline pulau" صائت ثنائي كما في & $\mathrm{Au}$ & $\Lambda$ \\
\hline صائت ثنائي كما في "sepoi" & $\mathrm{Oi}$ & 9 \\
\hline صائت ثنائي كما في "esei" & $\mathrm{Ei}$ & 1. \\
\hline 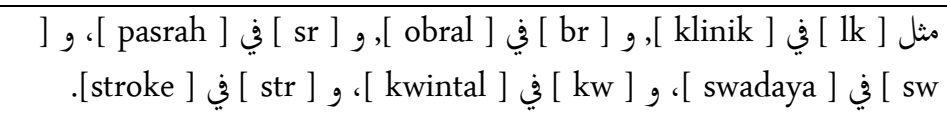 & صوامت ثنانية & 11 \\
\hline 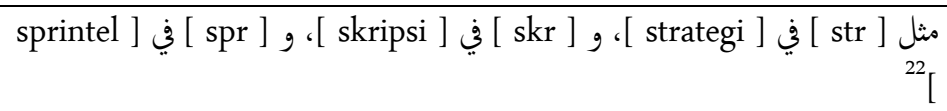 & صوامت ثلاثية & IT \\
\hline
\end{tabular}

\section{KESIMPULAN}

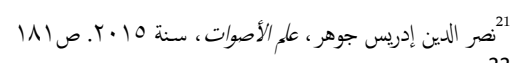

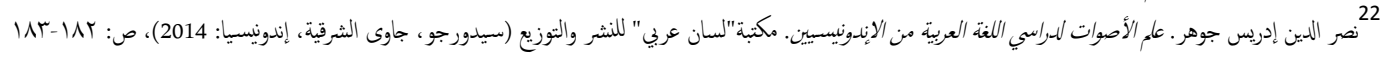


1. Studi komparatif nilai-nilai fonologi antara Bahasa Bahasa Arab dan Bahasa Indonesia

$$
\text { اـ أصوات في اللغتين بمكن وصفها بأنها متمثلة أو متطابقة(sama persis) لما لها من سلات صوتية }
$$

Suara dalam kedua bahasa Arab Atau Indonesia di mungkinkan sifatnya identik atau sama baik dari segi tempat keluarnya suara atau sifatnya.

$$
\text { r. أصوات في اللغتين يمكن وصفها بأها متشابهة (mirip) إذا أنها تتماثل و تتطابق في جميع السمات }
$$

Suara dalam kedua bahasa Arab Atau Indonesia di mungkinkan sifatnya mirip

2. Studi kontrastif nilai-nilai fonologi antara Bahasa Arab dan Bahasa Indonesia

$$
\begin{aligned}
& \text { ا ـ أصوات فى اللغتين يككن و صفها بأهها متخالفة لما بينها من اختلافات في السهات الصوتية سواء كانت } \\
& \text { من حيث الخخرج أو من حيث الصفة }
\end{aligned}
$$

Suara dalam kedua bahasa Arab Atau Indonesia di mungkinkan sifatnya berbeda baik dari segi tempat keluarnya suara atau sifatnya.

$$
\text { r. الأصوات العربية التي ليس لها مقابل في اللغة الإندونيسية، }
$$

Suara Bahasa Arab ada yang tidak sesuai dengan suara Bahasa Indonesia

$$
\text { r. الأصوات الإندونيسة التي ليس لها مقابل في اللغة العربية }
$$

Suara Bahasa Indonesia ada yang tidak sesuai dengan suara Bahasa Arab

\section{DAFTAR PUSTAKA}

Abû Rîda, Muhammad 'Abd al-hâdî, Rasâil al-Kindî al-Falsafah, Dâr al-Fikr al'Araby, 1952.

Anîs, Ibrahîm, 'Ilm al-Așwât, Maktabah al-Anjlû al-Miṣriyah, 1999.

Ayyub, 'Abd al-Rahman,. Așwat al-Lughah, Mațba'ah Al-Kaylânî, 1964. 
Al-Șafâ', Ikhwân, Rasâil Ikhwân Al-Șafâ', Dâr Ṣâdir, Beirut.

Bishr, Kamâl, 'Ilm al-Așwât, Dâr al-Gharîb, 2000.

Borg, W.R.\& Gall, M.D. Educational Research: An introduction . New York \& London: Longman.1979.

Chaer, Abdul. linguistik umum, Jakarta : PT. Rineka Cipta. 1994.

Chaer, Abdul. Fonologi bahasa Indonesia. Jakarta ; Rineka. 2009.

Dâla', Muhammad Șâliḥ, 'Ulûm al-Ṣautiyât 'Inda Ibn Sîbâ, Dâr al-Gharîb, 2002.

Ḥassâm al-Dîn Karîm Zakî, Ușûl Turathiah fî 'Ilm al-Lughah, Maktabah al-Anjlu alMișriyah.

Jauhar, Naṣar al-Dîn Idrîs, 'Ilm al-Așwât, Maktabah Lisan al’Araby, 2014.

Khalaf Khâlid Aḥmad, 'Ilm al-Aṣwât al-Hayawiyah 'Am Tatakallam al-Hayawânât li Shishkovskaya, Dâr 'Alâ' al-Dîn, al-Ṭab'ah al-ûlâ, 2004.

Marsono. Fonetik. Jogjakarta; Gajah Mada Univty. Press. 2006.

Mu'in, Abdul. Analisis kontrastif bahasa Arab \& bahasa Indonesia (telaah terhadap fonetik dan morfologi ). Jakarta ; PT. Pustaka Al-Husna Baru

Muslich, Mansur. Fonologi bahasa Indonesia. Jakarta; Bumi Aksara. 2008.

Pateda, Mansoer. Linguistik (sebuah pengantar), Bandung : Angkasa. 1990.

Sayuti Anshari Nasution, Ahmad. Bunyi Bahasa. Jakarta; Amzah. 2010.

Sahkholid. Pengantar Linguistik (analisis teori-teori linguistic umum dalam bahasa arab), Medan: Nara Press. 2006.

Schane. Fonologi Generatif, terj. Kentjanawati Gunawan. Jakarta: Summer Institute of Linguistics-Indonesia. 1992.

Sugiono. Metode Penelitian Kuantitatif Kualitatif dan R\&D. Bandung : Alfabata. 2008.

Suryabrata, Sumardi. Metodologi Penelitian. Jakarta: PT.Raja Grafindo Persada. 1998.

Sugiono. Statistik Untuk Penelitian. Bandung: Alfabeta, cet ke-17. 2010.

Sumadi, Muljanto. Pengajaran Bahasa Asing: Sebuah Tinjauan dari Segi Metodologi, Bulan Bintang, Jakarta. 1975. 
Umar, Ahmad Mukhtar. Dirasatu ash-Shauti al-Lughawiy. Cairo: Alamul Kutub. 1985.

Zahrân al-Badrawî, Fî 'Ilm al-Aṣwât al-Lughawiyah wa 'Uyûb al-Nuțqi, Dâr alMa'ârif, 1994. 